\title{
КОНСТИТУЦЙНІ ПРАВА ТА СВОБОДИ ЛЮДИНИ ЯК ОСНОВНИЙ КРИТЕРІЙ КОНСТИТУЦЙНОСТІ Й ЛЕГІТИМНОСТІ ПУБЛІЧНОЇ ВЛАДИ
}

\author{
Бліхар В. С., Бліхар М. М.
}

\section{ВСТУП}

Легітимність і конституційність тісно пов'язані між собою, хоча й виступають різними характеристиками такого явища, як державна влада. Легітимність - це сприйняття громадянами органів влади. Конституційність - це відповідність актів і дій органів державної влади Конституції як Основному Закону.

Населення оцінює владу за конкретні кроки, спрямовані на вирішення актуальних проблем у житті суспільства. Рівень оцінювання влади є надзвичайно мінливим, оскільки прямо залежить від щоденної діяльності органів влади, прийняття популярних чи непопулярних рішень. Підтвердженням цьому є численні соціологічні дослідження, проведені впродовж останніх десяти років. У цьому аспекті актуальними залишаються слова Ф. Гізо: «Жодна влада над людьми не звільнена від обов'язку доводити свою легітимність ... тією мірою, якою законна влада має право на свободу людини, свобода має право вимагати від влади доказів ії легітимності» ${ }^{1}$.

На нашу думку, над поняттям «легітимність» повинні спільно працювати науковці - представники таких галузей науки, як право, політологія, філософія, соціологія. Оскільки лише напрацювання, отримані від розгляду одного й того ж явища з погляду різного предмета, дадуть змогу якнайповніше його вивчити та розробити механізми впровадження й застосування, необхідні саме для конкретного суспільства, держави. Ці дослідження є актуальними особливо сьогодні, оскільки поняття «легітимність» є своєрідним мостом між правом і політикою, між законністю і справедливістю, між раціональністю й доцільністю2

Легітимність неможливо запровадити раз і назавжди. Цей процес повинен бути поступовим і здійснюватися в міру розвитку держави, щоб жоден з елементів легітимності не порушив їх балансу, що призведе, відповідно, до порушення балансу в державі.

\footnotetext{
1 Гизо Ф. Политическая философия: о суверенитете. Классический французский либерализм. Москва, 2000. С. 571.

2 Бліхар М.М. Конституційні права та свободи людини як основний критерій легітимності публічної влади. Сучасний конституціоналізм: проблеми теорії та практики : матеріали наукового семінару (м. Львів, 22 червня 2018 р.). Львів : ЛьвДУВС, 2018. С. 19. 
Сьогодні легітимність властива для стабільних демократичних держав громадянського суспільства. Це ті суспільства, у яких наявна прозора виборча система, відпрацьована процедура формування органів державної влади, високорозвинена судова система, великий відсоток правосвідомих і правослухняних громадян, розвинена соціальна сфера.

Ще одним поняттям, без якого публічна влада не може бути конституційною та легітимною, є поняття волевиявлення народу. Це закріплено в Конституції України, зокрема ст. 5 зазначено: «Носієм суверенітету і єдиним джерелом влади в Україні $є$ народ. Народ здійснює владу безпосередньо і через органи місцевого самоврядування» ${ }^{3}$. Тобто народ має виключне право на формування органів державної влади та місцевого самоврядування шляхом виборів, право на прийняття важливих політичних рішень, необхідних для забезпечення достойного рівня життя громадян.

Однак ніщо у світі не є ідеальним і жодна держава, навіть найбільш розвинена, держава, у якій сформовані органи влади всіх гілок, чітко відпрацьовані механізми їхньої діяльності, відповідальність за власні діï, не застрахована від збоїв у роботі добре налагодженого механізму державної влади. Основною причиною цього стає втрата довіри громадян до влади ${ }^{4}$.

\section{1. Конституційні права і свободи людини та громадянина в Україні}

Дослідники виділяють кілька причин такого явища: «суперечності, що існують між універсальними цінностями, які панують у суспільстві, та егоїстичними інтересами панівної еліти; значний розрив між діяльністю органів державної влади та реальними потребами суспільства, відсутність механізмів захисту інтересів особи; низький рівень відкритості державної влади, що часто не дає змоги не лише контролювати iї, а й узагалі визначати ті інтереси, на забезпечення яких реалізовується та чи інша державна політика; неготовність державної влади та громадянського суспільства взаємодіяти на основі паритетності, партнерства, взаємної довіри та взаємної відповідальності; відносно низький рівень правової й політичної культури як представників влади, так і суспільства загалом, неусталеність демократичних традицій, що властиві розвинутим демократіям; втрата правлячої еліти віри

\footnotetext{
3 Конституція України : Закон України від 28.06.1996 № 254к/96-BP. URL: http://zakon0. rada.gov.ua/laws/show/254к/96-вр (дата звернення: 20.02.2020).

4 Бліхар М.M. Конституційні права та свободи людини як основний критерій легітимності публічної влади. Сучасний конституціоналізм: проблеми теорії та практики : матеріали наукового семінару (м. Львів, 22 червня 2018 р.). Львів : ЛьвДУВС, 2018. С. 20.
} 
у свою правомірність, поява всередині неї гострих соціальних суперечностей, зіткнення різних гілок влади; зростання бюрократизації та корумпованості» ${ }^{5}$.

Уникнути таких ситуацій дає змогу постійний діалог між населенням і владою, чіткі схеми контролю діяльності органів державної влади та місцевого самоврядування, дотримання конституції та законів усіма сторонами суспільства.

У світовому співтоваристві в цій галузі є певні напрацювання. Це, зокрема, прийняття документів, які визнали та погодилися дотримуватися чимало держав. Серед них виділяють Загальну декларацію прав людини; Міжнародний пакт про економічні, соціальні і культурні права; Міжнародний пакт про громадянські і політичні права. Норми і стандарти, викладені в цих документах, ставлять вимоги до законодавства країн, які їх підтримали та схвалили. Легітимність як явище має велике значення для законотворчості. Через категорію справедливості вкладається правовий зміст у будь-який закон, а закон, у свою чергу, покликаний захищати справедливість.

Отже, з наведеного вище можемо зробити висновок, що поняття легітимності становлять справедливість і законність, які не можуть існувати одна без одної.

Однак у світовій практиці відомі випадки, коли відсутність одного із цих складників влада компенсує іншим. Це стосується передовсім держав, що тільки стали на шлях розвитку демократії.

Незадовільно обмежувати легітимність влади лише формально-юридичними ознаками, коли легітимність розуміють тільки як законність, коли політична система чи режим уважається легітимним, якщо має місце відповідність структур, процесів формування й функціонування влади відповідно до букви і духу чинного законодавства. Таке обмеження призводить до ототожнення легітимності та легальності й буває однією $з$ причин кризи легітимності влади. В історії держави та права є багато прикладів того, як досить успішна з формально-юридичного погляду, тобто легальна державна влада (яка сформована й функціонувала відповідно до матеріальних і процесуальних норм конституції та інших законодавчих актів), утрачала свою легітимність, через те що іiі рішення та закони мали, на думку громадян, несправедливий характер ${ }^{6}$.

\footnotetext{
5 Ковальчук В.Б., Іщук С.І. Громадянське суспільство та державна влада в процесі демократичної легітимації: теоретико-правові аспекти : монографія. Острог, 2013. 131 с.

6 Манжола П. До питання щодо науково-теоретичного розмежування сутнісного змісту категорій «легальність» та легітимність. Вибори та демократія. 2006. № 3. С. 40-42.
} 
Ще однісю причиною, через яку може бути втрачено легітимність влади, $є$ неправовий характер законів, які приймає така влада та на які вона опирається. Тобто нормативно-правовий акт повинен бути прийнятий відповідним органом у певному процесуальному порядку. Такі нормативно-правові акти вважаються формально легітимними. Ще однією стороною є змістовна легітимність: окрім умов формальної легітимності, нормативно-правовий акт має отримати підтримку населення.

Умовами легітимності закону $є$ прийняття відповідним органом; дотримання процесуального порядку під час прийняття, правозастосування.

В інших випадках, якщо населення усвідомлює, що політичні рішення та юридичні закони є несправедливими щодо більшості населення держави, у такій державі починають відбуватися процеси, спрямовані на повну зміну влади або чинного законодавства.

Права та свободи людини є основним критерієм конституційності й легітимності влади. У цьому випадку доцільно говорити про основні або ж конституційні права та свободи.

Уже традиційно права і свободи людини та громадянина поділяють на позитивні й негативні.

Права, які грунтуються на забороні втручання в певні сфери життя людини, називають негативними. Вони визначають ступінь свободи учасників певних суспільних відносин. Такі права убезпечують одну людину від іншої. До таких прав зараховують право на життя, право на приватну власність і право на свободу світогляду та віросповідання, права людини на ім’я, честь і гідність, права на свободу думки та слова, права на вільне пересування й вибір місця проживання, права на збереження конфіденційності інформації, яка стосується особи та його сім’ї, та деякі права та свободи.

Характерною особливістю цих прав і свобод є те, що вони є невідчужуваними, невід'ємними й абсолютними. Ці права та свободи не може порушити ні інша людина, ні держава, адже тоді остання втрачає свою легітимність. У правовій державі ці права та свободи повинні бути не просто проголошеними, а й стати частиною національного законодавства.

Права, які людина отримує впродовж життя в суспільстві, тобто в процесі взаємодії людини та держави, називають позитивними. До цих прав зараховують: право брати участь в управлінні державними справами; право обирати й бути обраним до представницьких 
органів державної влади та місцевого самоврядування; право створювати громадські об'єднання й брати участь у їхній діяльності; право мирно збиратися і проводити збори, мітинги, демонстрації, маніфестації $з$ метою підтримки чи критики діяльності органів влади та самоврядування чи окремих посадових осіб; право письмового чи особистого звернення до органів державної влади та місцевого самоврядування; право на свободу засобів масової інформації.

Як приклад розглянемо право на мирні зібрання, що мають на меті виступ проти певного чи певних законів, дій влади чи окремих посадових осіб, які, на думку протестувальників, мають нелегітимний характер. У певних випадках такі зібрання переростають в акції громадянської непокори. «Громадянський протест - це публічна, ненасильницька, свідома політична діяльність, яка, однак, спрямована проти нелегітимного закону і здійснюється, як правило, з метою змін у законодавстві чи політиці державної влади. Учасники громадянського протесту колективні суб' єкти апелюють до принципів конституційної демократії, до ідеї фундаментальних прав і свобод чи демократичної легітимності. Акції громадянської непокори посідають проміжне становище між конституційними формами політичної діяльності, з одного боку, і повстанням чи революцією - з іншого. Щоб громадянська непокора зберігала свою легальність і легітимність, необхідно щонайменше дві важливі умови. По-перше, громадянський протест повинен бути врегульований нормами чинного законодавства, які б установлювали чітку процедуру проходження акцій опору, із закріпленням прав та обов'язків учасників публічних акцій, а також гарантій реалізації цих прав. По-друге, легітимний характер громадянського опору значною мірою залежить від високого рівня правової та політичної культури як членів громадянського суспільства, так і представників органів державної влади та місцевого самоврядування?.

Позитивні права дають людині змогу захищати свої негативні права законним шляхом.

Одним із найбільш важливих принципів конституційності й легітимності публічної влади є принцип народного суверенітету. Цей принцип «є одним із основоположних принципів конституційної держави, який проголошує народ носієм суверенітету та єдиним джерелом влади у державі. Відповідно до цього принципу народ постає активним учасником політичного процесу i безпосередньо (чи опосередковано)

\footnotetext{
7 Ковальчук В.Б., Іщук С.І. Громадянське суспільство та державна влада в процесі демократичної легітимації: теоретико-правові аспекти : монографія. Острог, 2013. С. 141-142. 
здійснює владарювання. Присутність цього принципу в правовій ідеології також передбачає, що народ здійснює контроль за діяльністю органів влади і у разі втрати ними довіри громадян їх носії можуть бути усунуті від публічної влади правомірним способом» ${ }^{8}$.

Права і свободи людини та громадянина є своєрідним еталоном, критерієм оцінювання діяльності законодавчих і виконавчих органів державної влади та місцевого самоврядування, ефективність існування того чи іншого політичного інституту.

Права і свободи як проголошена цінність знаходять практичне застосування лише за умови їх визнання й дотримання владою. Влада стає легітимною тоді, коли неухильно дотримується й відстоює права i свободи своїх громадян. Тобто права і свободи людини та громадянина перебувають у постійному взаємозв'язку з публічною владою. Стосовно цієї тези Ф. Гізо говорив: «Тою мірою, якою законна влада наділена правом на свободу людини, свобода має право вимагати від влади доказів її легітимності»?.

Сьогодні одним із атрибутів правової держави є законодавче закріплення прав і свобод людини та громадянина. Повага держави до людини та громадянина через повагу до його прав і свобод викликає в громадянина повагу до держави через повагу до ії законів.

За сучасних умов не $є$ винятком і сьогоднішня Україна, є надання людині права протестувати проти дій влади. Виявом такого права $\epsilon$ право на протест ${ }^{10}$. Так, Конституція України гарантує права людям на мирні зібрання, мітинги, походи й демонстрації. Також Основний Закон гарантує тим, хто працює, право на страйк для захисту своїх економічних і соціальних інтересів. Такі права належать до політичних прав і свобод і є нерозривно пов'язаними з особистими правами і свободами людини та громадянина.

Це право є водночас і своєрідною гарантією захисту інших прав i свобод. Завдяки праву на страйк громадськість може впливати на роботу органів влади та місцевого самоврядування, викликаючи тим самим прийняття тих рішень, які необхідні для суспільства, контролювати процес їх приведення в дію та результативність.

\footnotetext{
8 Ковальчук В.Б., Іщук С.І. Громадянське суспільство та державна влада в процесі демократичної легітимації: теоретико-правові аспекти : монографія. Острог, 2013. С. 31.

9 Гизо Ф. Политическая философия: о суверенитете. Классический французский либерализм. Москва, 2000. С. 571.

10 Бліхар М.М. Конституційні права та свободи людини як основний критерій легітимності публічної влади. Сучасний конституціоналізм: проблеми теорії та практики : матеріали наукового семінару (м. Львів, 22 червня 2018 р.). Львів : ЛьвДУВС, 2018. С. 21.
} 
Воно викликає і взаємну відповідальність держави та громадянина, адже як влада, так і народ зобов'язані дотримуватися певних правил і процедур навіть у період непорозуміння. Перше, що необхідно буде зробити для примирення обом сторонам, - це сісти за стіл переговорів. Наслідком таких переговорів повинна стати взаємовигідна для обох сторін пропозиція, відображена в нормативно-правовому акті.

Влада вважається легітимною тоді, коли вона відповідає уявленням людей про право, справедливість і провадить свою діяльність в інтересах народу. Тобто це влада, визнана народом.

Легітимність публічної влади - це динамічна система взаємовідносин між владою та громадянами, яка побудована на визнанні громадянами встановленого порядку й функціонування органів влади та їх готовності свідомо діяти відповідно до встановлених державою правил.

На перший погляд може здатися, що конституційність і легітимність - це поняття, які стосуються виключно компетенції держави. Однак насправді це не так. Задля забезпечення конструктивної взаємодії між державою та людиною до управління державою необхідно залучати й інститути громадянського суспільства. Так, уважаємо, що створення певних дорадчих органів при міністерствах і відомствах, залучення пересічних громадян до прийняття важливих політичних рішень і законів сприятиме не лише вдосконаленню діалогу у форматі «людина - держава», а й дасть змогу більш швидко приймати рішення, які будуть позитивно сприйняті населенням і необхідними для покращення життя людей.

\section{2. Конституціоналізм і можливості обмеження прав людини}

Провідною ідеєю, на яку сьогодні опираються в процесах державного будівництва та правотворення, є необхідність залучення до правомірної поведінки якнайбільшої кількості людей і демократизація, гуманізація права й держави в іiі ставленні до людини. Це насамперед $\epsilon$ вигідним державі, оскільки допомагає уникнути багатьох проблем, пов'язаних із наслідками вчинення злочинів і правопорушень, неправомірною поведінкою великої кількості людей. Однак і для самої людини має позитивні наслідки - безпечне середовище для життєдіяльності, наявність можливостей для повноцінного розвитку особистості, отримання гарантованих державою прав і свобод, які не можуть бути порушені чи обмежені. 
Власне, наявність прав і свобод і можливість їх відновлення в разі порушення чи обмеження $є$ своєрідною гарантією для самої людини щодо наявності механізмів захисту від свавілля як інших людей, так і держави. Це певна демонстрація спроможності держави захистити людину, декларування ii цінності. Саме 3 такою метою й виникло поняття конституціоналізму - системи, яка є гарантом демократії, обгрунтовує людиноцентричну модель суспільства та засобом забезпечення конституційного характеру держави.

«Вихідною ідеєю конституціоналізму, що визначає мету його існування, є забезпечення свободи людини, гарантування ії прав, а засобом досягнення цієї мети є обмеження свавілля держави, введення державної влади в певні юридичні межі іiі функціонування, що убезпечить іiі від надмірного втручання у сферу свободи індивіда» ${ }^{11}$. Тобто конституціоналізм - це засіб обмеження свавілля державної влади, це спосіб захисту людини, іiі прав і свобод, де людина, іiї права і свободи посідають центральне місце.

Людина від народження володіє певним набором прав і свобод, які не залежать від держави, у якій вона народилася чи проживає. Однак самі по собі ці права не мають жодного значення для держави, саме тому на певному етапі розвитку права та держави виникла необхідність їх юридичного закріплення. Цьому передувала титанічна робота правознавців, філософів, державних діячів, які впродовж багатьох років доводили необхідність проголошення природних прав i свобод людини на юридичному рівні, обгрунтовували доцільність цього насамперед для держави, її подальшого розвитку та функціонування. Таке декларування прав і свобод стало своєрідним поворотом держави до людини, визнання кожної людини цінністю й цінності кожної людини.

«Природні права людини набувають свого практичного втілення (реалізації) через їх нормативне закріплення в конституції та законах держави. Сучасний конституціоналізм із його основними правами людини - єдина реалістична імплементація цінностей природного права в сучасному світі. Включення основних прав і свобод у конституцію - означає прийняття державою зобов'язання не порушувати ці права» ${ }^{12}$.

\footnotetext{
11 Бориславська О. Сутність конституціоналізму: конституціоналізм як ідеологія, доктрина та практика обмеженого правління. Вісник Львівського університету. Серія «Юридична». 2015. Вип. 61. С. 249.

12 Ковальчук В.Б. Легітимність державної влади в правовій теорії та державно-правовій практиці : монографія. Київ : Логос, 2011. С. 203.
} 
Однак існують випадки, коли порушення конституційних прав і свобод однієї людини допоможе захистити багатьох людей, а то й державу, створить гарантії для мирного співіснування людей та держав.

Згідно зі ст. 64 Конституції України ${ }^{13}$, конституційні права і свободи людини та громадянина не можуть бути обмежені, крім випадків, передбачених Конституцією України. В умовах воєнного або надзвичайного стану можуть установлюватися окремі прав і свобод із зазначенням строку дії цих обмежень.

Так, нещодавно частина українців зіткнулася з такими обмеженнями через Указ Президента України «Про введення воєнного стану в Україні» ${ }^{14}$. У цьому Указі зазначалося, що «у зв'язку із введенням в Україні воєнного стану тимчасово, на період дії правового режиму воєнного стану, можуть обмежуватися конституційні права і свободи людини і громадянина, передбачені статтями 30-34, 38, 39, 41-44, 53 Конституції України, а також уводитися тимчасові обмеження прав і законних інтересів юридичних осіб у межах та обсязі, що необхідні для забезпечення можливості запровадження та здійснення заходів правового режиму воєнного стану» ${ }^{15}$

Також у Конституції України встановлено певні обмеження щодо реалізації певних прав і свобод однією людиною відносної іншої та відносно держави. Наприклад, ст. 32 Конституції України твердить: «Ніхто не може зазнавати втручання в його особисте і сімейне життя, крім випадків, передбачених Конституцією України. Не допускається збирання, зберігання, використання та поширення конфіденційної інформації про особу без її згоди, крім випадків, визначених законом, і лише в інтересах національної безпеки, економічного добробуту та прав людини» ${ }^{16}$. Право вільно збирати й використовувати інформацію, гарантоване ст. 34 Конституції України, законодавець обмежує в інтересах державної безпеки та громадського порядку. Ті самі обмеження стосуються норм, прописаних у ст.ст. 35, 36, 39 Конституції України. Обмеження прав i свобод людини та громадянина,

13 Конституція України : Закон України від 28.06.1996 № 254к/96-BP. URL: http://zakon0.rada.gov.ua/laws/show/254к/96-вр (дата звернення: 20.02.2020).

14 Про затвердження Указу Президента України «Про введення воєнного стану в Україні» від 26 листопада 2018 р. № 2630-VIII. URL: https://zakon.rada.gov.ua/laws/main/2630-19 (дата звернення: 20.02.2020).

15 Про затвердження Указу Президента України «Про введення воєнного стану в Україні» від 26 листопада 2018 р. № 2630-VIII. URL: https://zakon.rada.gov.ua/laws/main/2630-19 (дата звернення: 20.02.2020).

16 Конституція України : Закон України від 28.06.1996 № 254к/96-BP. URL: http://zakon0.rada.gov.ua/laws/show/254к/96-вр (дата звернення: 20.02.2020). 
висвітлені в указаних статтях, спрямовані передусім на захист прав і свобод самих людей, кожної людини конкретно та держави як сукупності людей, наділених певними правами й обов'язками.

Загальна декларація прав людини ${ }^{17}$ як міждержавний нормативноправовий акт також визначає умови, за яких може бути обмежено права і свободи людини: під час здійснення своїх прав і свобод кожна людина повинна зазнавати тільки таких обмежень, які встановлені законом виключно з метою забезпечення належного визнання й поваги прав і свобод інших людей і забезпечення моральних вимог, громадського порядку й загального добробуту в демократичному суспільстві.

Відповідно до обставин, за яких уводиться обмеження прав і свобод, виділяють загальне та індивідуальне обмеження.

Загальне обмеження прав і свобод людини та громадянина зазвичай пов'язане з певними подіями в державі, які зумовили необхідність уведення певного стану: надзвичайного чи воєнного. Уведення цих режимів додатково регулюється відповідними законами.

Так, Закон України «Про правовий режим надзвичайного стану» ${ }^{18}$ визначає зміст правового режиму надзвичайного стану, порядок його введення та припинення дії, особливості діяльності органів державної влади й місцевого самоврядування, підприємств, установ та організацій в умовах надзвичайного стану, додержання прав і свобод людини та громадянина, а також прав і законних інтересів юридичних осіб і відповідальність за порушення вимог або невиконання заходів правового режиму надзвичайного стану. Зокрема, у ст. 22 цього Закону зазначено: «Правовий статус та обмеження прав і свобод громадян та прав і законних інтересів юридичних осіб в умовах надзвичайного стану визначаються відповідно до Конституції України. ...

В умовах надзвичайного стану не можуть бути обмежені права і свободи людини і громадянина, зазначені у частині другій статті 64 Конституції України» ${ }^{19}$.

Законом України «Про правовий режим воєнного стану» ${ }^{20}$ визначено зміст правового режиму воєнного стану, порядок його введення та скасування, правові засади діяльності органів місцевого

17 Загальна декларація прав людини. URL: http://zakon3.rada.gov.ua/laws/show/995_015 (дата звернення: 20.02.2020).

18 Про правовий режим надзвичайного стану: Закон України від 16 березня 2000 р. № 1550-III. URL: http://zakon2.rada.gov.ua/laws/show/1550-14 (дата звернення: 20.02.2020).

19 Там само.

20 Там само. 
самоврядування, підприємств, установ, органів державної влади, військового командування в умовах воєнного стану, гарантії прав і свобод людини та громадянина, прав і законних інтересів юридичних осіб, відповідальність за порушення вимог або невиконання заходів правового режиму воєнного стану.

В умовах воєнного стану не можуть бути обмежені права і свободи людини та громадянина, які передбачені в ч. 2 ст. 64 Конституції України.

Індивідуальне обмеження прав і свобод людини та громадянина застосовується щодо конкретної людини. Власне, цей вид обмеження прав і свобод людини та громадянина прямо залежить від самої людини, її поведінки. За вчинення певного порушення закону до особи може бути застосовано такий вид покарання, як, скажімо, громадські або виправні роботи. Тобто впродовж певного часу людина повинна виконувати суспільно корисну працю. Такий вид обмеження щодо однієї людини застосовують з метою гарантування прав і свобод інших людей. Однак, незважаючи на обмеження прав і свобод, держава все ж таки гарантує такій людині право на оплату праці, право на відпочинок, право на охорону здоров'я.

Сьогодні в Україні розроблена, прийнята й діє низка законів, які через певні обмеження прав і свобод людини та громадянина, покликані забезпечувати державний суверенітет, громадський порядок, захист прав і свобод людей. До цього переліку можна зарахувати нормативно-правові акти різних галузей права, однак об'єднаних метою забезпечення та захисту конституційних прав і свобод людини та громадянина: Кримінальний процесуальний кодекс України; Закон України «Про оперативно-розшукову діяльність»; Закон України «Про контррозвідувальну діяльність»; Закон України «Про організаційно-правові основи боротьби з організованою злочинністю».

Ці акти права допускають обмеження права на недоторканність житла, таємницю листування, невтручання в особисте життя людини на період проведення оперативно-розшукових заходів і досудового розслідування. Однак поряд і цим у них містяться чіткі вказівки на неприпустимість розголошення відомостей особистого характеру, що стали відомі в процесі проведення певних дій, проте не мають стосунку до справи, через яку накладено обмеження прав і свобод людини та громадянина на конкретну особу.

Такі закони України, як Закон України «Про свободу пересування та вільний вибір місця проживання», Закон України «Про порядок 
виїзду з України і в’їзду в Україну громадян України» встановлюють за певних обставин обмеження на такі конституційні права і свободи: право на свободу пересування; право на вільний вибір місця проживання тими особами, які на законних підставах перебувають на території нашої держави; право вільно залишати територію України.

Для захисту інтересів як держави, так і людини законом може бути тимчасово обмежено й такі права і свободи людини та громадянина: право на свободу думки і слова; право на вільне вираження своїх поглядів і переконань; право вільно збирати, зберігати, використовувати й поширювати інформацію; право на свободу світогляду й віросповідання; право на свободу об'єднання в політичні партії та громадські організації для здійснення й захисту своїх прав і свобод і задоволення політичних, економічних, соціальних, культурних та інших інтересів; право на мирне зібрання, проведення мітингів, демонстрацій, зборів. Особливістю обмеження цього права є те, що лише суд може встановити заборону на проведення подібних акцій. Підставами для прийняття такого рішення можуть бути загроза національній безпеці, громадському порядку; право кожної особи володіти, користуватися й розпоряджатися своєю власністю; право на здійснення підприємницької діяльності для окремих категорій населення - народних депутатів, державних службовців, працівників силових структур; право тих, хто працює, на страйк.

Український дослідник Олександр Скрипнюк уважає, що «обмеження прав і свобод людини - це передбачений Конституцією та законами України режим тимчасового загального або конкретно-індивідуального призупинення чи звуження обсягу визначених і гарантованих Основним Законом прав і свобод в інтересах забезпечення прав інших людей, а також забезпечення національної безпеки і оборони України. Як випливає зі змісту ст. 64, обмеження конституційних прав і свобод людини не може бути абсолютним і має свої хронологічні, процедурні та, врешті, предметні межі» ${ }^{21}$.

Обмеження прав і свобод людини та громадянина є однією з умов конституціоналізму та як явище має низку характерних ознак: $є$ вимушеним заходом, який застосовується у виняткових випадках; є визначеним у часі; здійснюється в порядку, чітко визначеному законодавством; коло суб'єктів, які можуть установлювати певні обмеження та щодо яких може бути застосовано обмеження, є визначеним на

21 Скрипнюк О. Конституційно-правове регулювання обмеження прав і свобод людини і громадянина в Україні. Публічне право. 2011. № 3. С. 5-11. 
законодавчому рівні; існує визначений перелік прав і свобод, які не можуть бути обмежені за жодних обставин; будь-які спроби обмежити права і свободи людини та громадянина незаконним шляхом тягнуть за собою юридичну відповідальність.

Сучасну систему прав і свобод, обов'язків людини та громадянина, яка сьогодні діє в Україні, розроблено як з урахуванням національних традицій державотворення та правотворення, а також із дотримання міжнародних стандартів у сфері забезпечення й захисту прав і свобод людини та громадянина. Серед міжнародних нормативно-правових актів, які Україна ратифікувала та імплементувала до національного законодавства, варто відзначити Загальну декларацію прав людини, Міжнародний пакт про громадянські та політичні права, Міжнародний пакт про громадянські, соціальні та культурні права, Свропейську конвенцію про права і основні свободи людини.

Урешті-решт, держава володіє виключним правом на застосування примусу. Це право їй делегувала людина, яка натомість отримала гарантії захисту, безпеки та визнання й дотримання державою тих прав і свобод, які забезпечать їй можливості для гідного життя та розвитку себе як особистості. А державний примус сьогодні є скоріше засобом впливу держави на людину з метою формування в неї усвідомленої необхідності вчиняти правомірно задля досягнення загального блага - побудови правової держави та громадянського суспільства. Тому застосування обмеження прав і свобод не є показником недосконалості тієї чи іншої держави загалом і ії правової системи зокрема, а $є$ однією з умов конституціоналізму.

\section{ВИСНОВКИ}

Отже, обмеження прав і свобод людини та громадянина є своєрідним відображенням діяльності людини. Тобто людина, яка вчиняє відповідно до вимог норм законів, не зазнаватиме жодних індивідуальних обмежень своїх прав і свобод. I, навпаки, людина, яка порушує норми й приписи закону, буде обмежена у своїх права i свободах. Людина, яка вчиняє правомірно, отримує додаткові права, недоступні для тих, хто порушує закон (наприклад, можливість вільного пересування, водіння автомобіля, участі у виборах, зайняття певних посад тощо).

Обмеження прав і свобод має і своєрідний позитивний вплив, оскільки є засобом забезпечення прав і свобод людини та громадянина шляхом спонукання до правослухняних учинків, дотримання 
всіх норм і приписів, установлених законодавством. А наслідком такої поведінки стане для людини отримання певних суспільних благ.

Конституція України закріпила основні права і свободи людини та громадянина. Деякі з них є непорушними (право на життя, право на охорону здоров'я тощо), інші ж можуть бути обмеженими (право на вільне висловлювання, право на вільне пересування тощо). Саме держава через Конституцію $є$ гарантом їх дотримання: поряд із обмеженнями, яких зазнає людина, законодавством передбачено шляхи для відновлення обмежених прав, кожному гарантується право на отримання інформації щодо причин обмеження його прав і свобод, право на звернення до суду за відновленням свого порушеного або обмеженого права. Тобто існують конституційно гарантовані засоби захисту від свавілля держави, перевищення владних повноважень посадовими особами відносно пересічних людей.

\section{АНОТАЦІЯ}

Права та свободи людини є основним критерієм конституційності й легітимності влади та є своєрідним еталоном, критерієм оцінювання діяльності законодавчих і виконавчих органів державної влади та місцевого самоврядування, ефективністю існування того чи іншого політичного інституту. Сьогодні одним із атрибутів правової держави є законодавче закріплення прав і свобод людини та громадянина. Повага держави до людини та громадянина через повагу до прав і свобод викликає в громадянина повагу до держави через повагу до іiі законів. Саме держава через Конституцію є гарантом їх дотримання: поряд із обмеженнями, яких зазнає людина, законодавством передбачено шляхи для відновлення обмежених прав, кожному гарантується право на отримання інформації щодо причин обмеження його прав і свобод, право на звернення до суду за відновленням свого порушеного або обмеженого права. Крім того, необхідно виокремити конституційність як своєрідний критерій для оцінювання громадянами політичної системи загалом та окремих органів влади зокрема. Основною умовою існування конституційності є опора чинної влади на конституцію та закони держави. Отже, конституційність і легітимність два взаємопов'язаних поняття. Хоча конституційність не завжди передбачає легітимність влади, легітимність же не може існувати без певних гарантій, які можуть бути відображені в законодавстві. 


\section{ЛІТЕРАТУРА}

1. Бліхар В.С. Гносеологічні та онтологічні складові правового статусу людини та громадянина в Україні. Український соиіум: соизіальнополітичний аналіз сучасності та прогноз майбутнього: збірник матеріалів XXI Всеукраїнської конференції викладачів, молодих вчених (м. Харків, 4 грудня 2019 р.). Харків : Право, 2019. С. 6-14.

2. Бліхар М.М. Конституційні права та свободи людини як основний критерій легітимності публічної влади. Сучасний конституціоналізм: проблеми теорії та практики : матеріали наукового семінару (м. Львів, 22 червня 2018 р.). Львів : ЛьвДУВС, 2018. С. 19-23.

3. Бліхар М.М. Конституціоналізм та можливості обмеження прав людини. Конституціоналізм та основи демократії: теоретико-правовий вимір : монографія : 2 ч. / за заг. редакцією д. ю. н., проф. В.Б. Ковальчука. Львів, 2019. Ч. 1. С. 228-238.

4. Бориславська О. Сутність конституціоналізму: конституціоналізм як ідеологія, доктрина та практика обмеженого правління. Вісник Львівського університету. Серія «Юридична». 2015. Вип. 61. C. 247-256.

5. Гизо Ф. Политическая философия: о суверенитете. Классический французский либерализм. Москва : РОССПЭН, 2000. 592 с.

6. Забокрицький I.I. Основні аспекти сучасного розуміння конституціоналізму. Вісник Національного університету «Львівська політехніка». Серія «Юридичні науки». 2015. № 827. С. 53-60.

7. Загальна декларація прав людини. URL: http://zakon3.rada.gov.ua/ laws/show/995_015 (дата звернення: 20.02.2020).

8. Ковалів М.В., Гаврильців М.Т., Бліхар М.М. Конституційне право України : навчальний посібник. Львів : Ліга-прес, 2014. 402 с.

9. Ковальчук В.Б. Легітимність державної влади в правовій теорії та державно-правовій практиці : монографія. Київ : Логос, 2011. 392 с.

10. Ковальчук В.Б., Іщук С.I. Громадянське суспільство та державна влада в процесі демократичної легітимації: теоретико-правові аспекти : монографія. Острог, 2013. 131 с.

11. Конституція України : Закон України від 28.06.1996 № 254к/96-ВР. URL: http://zakon0.rada.gov.ua/laws/show/254к/96-вр (дата звернення 20.02.2020).

12. Манжола П. До питання щодо науково-теоретичного розмежування сутнісного змісту категорій «легальність» та легітимність. Вибори та демократія. 2006. № 3. С. 40-42.

13. Про затвердження Указу Президента України «Про введення воєнного стану в Україні» від 26 листопада 2018 р. № 2630-VIII. URL: https://zakon.rada.gov.ua/laws/main/2630-19 (дата звернення: 20.02.2020). 
14. Про правовий режим надзвичайного стану: Закон України від 16 березня 2000 p. № 1550-III. URL: http://zakon2.rada.gov.ua/laws/ show/1550-14 (дата звернення: 20.02.2020).

15. Савчин М.В. Сучасні тенденції конституціоналізму в контексті глобалізації та правового плюралізму: монографія. Ужгород : РІК-У, 2018. 439 c.

16. Скрипнюк О. Конституційно-правове регулювання обмеження прав і свобод людини і громадянина в Україні. Публічне право. 2011. № 3. C. $5-11$.

17. Blikhar V., Blikhar M. Human rights as a base for the implementation of European legal values in Ukraine and the Republic of Poland in the context of cevil society development: Collective monograph. Lublin : Izdevnieciba "Baltija Publishing", 2019. 356 p.

\section{Information about authors:}

Blikhar M. M.,

Doctor of Juridical Sciences, Docent, Associate Professor of the Department of Constitutional and International Law

Institute of Jurisprudence and Psychology of the Lviv Polytechnic National University 1/3, Knyaz Roman str., Lviv, Ukraine

Blikhar V. S.,

Doctor of Philosophical Sciences, Professor, Head of the Department of Philosophy and Political Science Lviv State University of Internal Affairs 26, Horodotska str., Lviv, Ukraine

DOI https://doi.org/10.30525/978-9934-588-43-3/1.23 